\title{
Evaluation of Physico-Chemical and Fungal Species Associated with Oil Contaminated Soil from Selected Automobile Garage in Sokoto Metropolis
}

\author{
Hassan Muhammad Maishanu ${ }^{1}$, Ahmad Bashir ${ }^{1}$, Kasimu Shehu ${ }^{1}$, \\ Muhammad Murtala Mainasara ${ }^{2}$, Ibrahim Muhammad Magami ${ }^{1}$ \\ ${ }^{1}$ Usmanu Danfodiyo University \\ P. M. B. 2346, Sokoto, Nigeria \\ ${ }^{2}$ Universiti Tun Hussein Onn Malaysia \\ 101 Parit Raja, Batu Pahat, Johor, 86400, Malaysia
}

DOI: $10.22178 /$ pos.32-6

LCC Subject Category:

QH540-549.5

Received 05.12.2017

Accepted 08.01.2018

Published online 11.03.2018

Corresponding Author:

Muhammad Murtala Mainasara

mmgusau96@gmail.com

(c) 2018 The Authors. This

article is licensed under a

Creative Commons

Attribution 4.0 License

\begin{abstract}
This study was conducted with a view to evaluating the physicochemical and mycological properties of different oil contaminated soils collected from three different automobile garages in Sokoto Metropolis, and uncontaminated soil from the temporary site, Usmanu Danfodiyo University, Sokoto (UDUS) was used as the control. The $\mathrm{pH}$ was determined using $\mathrm{pH}$ meter model Hanna (H1991301), quantity of mineral elements was evaluated in accordance with Murphy and Fungi were isolated from the three oil contaminated samples (A, B. and C) and the uncontaminated (sample D) as control, this was done by standard procedure using the method of P. Ren, T. Jankun \& B. Leaderer. The physical, chemical, and mineral elements from the oilcontaminated soils of the three automobile garages and control. The results of particle soil analysis revealed the high content of sandy soil (96.2 to 87.3) and silt is the lowest with (2.5-0.6). Magnesium had the highest concentration of studied minerals, ranging from 193 to $649.2 \mathrm{mg} / \mathrm{kg}$. while $\mathrm{PH}$ result revealed that the soil samples were $\mathrm{pH}$ value ranged from $(16.85-16.20)$ in oil Contaminated samples, while the control had 15.90 , and electrical conductivity ranged from 12.8-13.8 \% and $28 \%$ in control, four fungal isolates Aspergillus $s p$. . Penicillum sp., Mucor sp. and Sporobolomyces $s p$. were identified based on colonial, sexual and morphological characteristics. These fungal strains can be used in bioremediation process and oil pollution reduction in aquatic ecosystems.
\end{abstract}

Keywords: automobile garages; physicochemical; mycological; Fungi; contamination.

\section{INTRODUCTION}

Soil is the naturally occurring, unconsolidated or loose covering on the earth's surface. Soil is made up of broken rock particles that have been altered by chemical and environmental conditions, such as weathering and erosion. Soil is a mixture of mineral and organic constituents that are in solid, gaseous and aqueous states. Soil bacteria and fungi play pivotal roles in various biogeochemical cycles (BGC) and are responsible for the cycling of organic compounds. Soil microorganisms also influence above-ground ecosystems by contributing to plant nutrition, soil structure, tex- ture and fertility $[1,8,14]$. Pollution in the environment is the unfavourable alteration of our environment as a result of wastes from man's activities, changes in radiation levels, physicochemical characteristics and abundance of organisms in a harmful way. However, a pollutant is a substance that occurs in the environment, at least in part, as a result of human activities, and which has deleterious effect on the environment $[10,19]$, in another words, pollution is the presence of harmful products of man activities, chemicals or other alteration of the natural soil environment. This type of contamination typically arises from the rupture of underground 
tanks as a result of the application of pesticides, percolation of contaminated surface water to subsurface strata, leaching of wastes on landfills or direct discharge of Industrial waste to the soil that results from accidental discharge of oil and its derivatives $[25,27]$.

With urban industrialization, social development and population increases, solid waste production are growing rapidly, making pollution a serious problem. If not properly disposed and managed the resulting environmental impact from these wastes can be disastrous [21]. Some of the obvious consequence of man-made pollution includes transmission of diseases by water borne pathogens, accumulation of toxic or recalcitrant chemicals in the soil, destabilization of ecological balance and negative effects on human health $[7,14$, $20,24]$. As a result of change in land use and accumulation of non-biodegradable wastes pointed out, there is need to determine the soil properties for proper management planning. These properties or parameters includes: soil $\mathrm{pH}$, particles size, organic matter/carbon content, macro and micro element content among others. The collected soil data can be used to assess the soils capacity to perform its ecological functions [20]. The knowledge of the soil PH will enable understanding the varying amount of plant nutrients present in the soil and give a level of microbial activities in the soil. Most arid and semi-arid soils have $\mathrm{pH}$ within the range of 6.0-6.8 $[6,15]$. Soil texture is a term used to designate the proportionate distribution of the different sizes of mineral particles in a soil; it does not contain any organic matter. These mineral particles vary in size from those easily seen with the unaided eye to those below the range of a high-powered microscope $[5,12,13]$. Soil texture is determined by the relative proportions of sand, silt, and clay found in a given soil. Author [12] stated that oil spillage on soil makes it unsatisfactory for plant growth. This is due to insufficient aeration of the soil because of the displacement of air from the space between the soil particles by petroleum byproducts. The petroleum stations and retail outlets are responsible for a number of environmental pollution resulting from accidental spills of oils and its derivatives [5].

Microbial communities exposed to hydrocarbon become adapted exhibiting selective enrichment and genetic changes resulting in increasing proportion of hydrocarbon degrading bacteria, and fungi. Bacterial plasmid encoding hydrocarbon catabolic genes and fungi makes them potential degraders of oil. For Fungi, some are opportunis- tic and affect a susceptible host while some are truly pathogenic $[3,9]$.

Automobile workshops abound within Sokoto metropolis. This has resulted in the concomitant exposure of the surrounding soils within the vicinity of these workshops to high levels of spent crankcase engine oil and lubricating oils $[4,23]$. This study was conducted with the aim of isolating and identifying the fungal species from soils collected from three different auto mechanic workshops within Sokoto metropolis and evaluation of their physicochemical characteristics.

\section{MATERIALS AND METHODS}

Source of soil samples. The study was carried out in selected areas of Sokoto metropolis. The city is located between latitude $5^{\circ} 09^{\prime} \mathrm{E}$ and $5^{\circ} 18^{\prime} \mathrm{E}$, Longitude $12^{\circ} 57^{\prime} \mathrm{N}$ and $13^{\circ} 07^{\prime} \mathrm{N}$, at $308 \mathrm{~m}$ above sea level. The River Sokoto partially surrounds the metropolis on the northwest axis. The three different automobile garages which are the Buzaye Auto mechanic Workshop, Sahara Automobile Engineering workshop and Tashar Illela garage are located at different sites of the Sokoto Metropolis. Automotive repairs and maintenance are the main activities going on in the automobile garages. This involves the indiscriminate disposal of various petroleum oils on the soil surfaces in substantial amounts.

Identification of Fungal Isolates. Fungi were isolated from the three oil contaminated samples (A, $\mathrm{B}$ and $\mathrm{C}$ ) and the uncontaminated (sample D) as control. This was done by standard procedure using the method of $[11,26]$.

Physicochemical Evaluation and Analysis. The three oil contaminated soil samples (A, B, and, C), and the uncontaminated soil (sample D) were physically and chemically evaluated to determine moisture, texture, $\mathrm{pH}$. As well as cation exchange capacity (C. E. C). The quantity of mineral elements such as Nitrogcn (N), Magnesium (M), Calcium (Ca), Phosphorus (P), Sodium (Na), Potassium (K), Organic carbon and Organic matter content were also measured using the methods of [17] in accordance with $[18,28]$. The $\mathrm{pH}$ was determined using $\mathrm{pH}$ meter model Hanna (H1991301) [16]. The Potassium, Nitrogen, and Phosphorus were determined using Flame photometer machine. Statistical Analysis was conducted using SPSS statistical package software version 20.0 using Dunnett tests to treat one group as a control, and compare all other groups against it [30]. 


\section{RESULTS AND DISCUSSION}

Results of physiochemical parameters are presented in Table 1.

Table 1 - Physicochemical Properties of Oil

Contaminated and Uncontaminated Soils

\begin{tabular}{|c|c|c|c|c|}
\hline Parameters & \multicolumn{4}{|c|}{ Samples } \\
\hline Soil (\%) & A & B & $\mathrm{C}$ & D \\
\hline Sand & 95.1 & 87.3 & 95.1 & 96.2 \\
\hline Silt & 0.6 & 0.11 & 0.8 & 2.5 \\
\hline Clay & 4.3 & 4.0 & 4.5 & 2.5 \\
\hline Elements (\%) & A & $\mathrm{B}$ & $\mathrm{C}$ & $\mathrm{D}$ \\
\hline Nitrogen & 0.098 & 0.095 & 0.053 & 1.035 \\
\hline Magnesium & 16.85 & 16.20 & 16.25 & 15.90 \\
\hline Calcium & 1.05 & 1.35 & 1.00 & 0.45 \\
\hline Phosphorus & 8.20 & 6.99 & 4.58 & 7.00 \\
\hline Potassium & 5.13 & 7.18 & 6.44 & 2.0 \\
\hline Sodium & 2.70 & 2.91 & 2.52 & 0.2 \\
\hline Carbon & 0.84 & 0.16 & 0.36 & 0.28 \\
\hline Organic con & 0.96 & 0.08 & 0.68 & 0.20 \\
\hline Organic matter & 1.68 & 0.14 & .045 & 0.34 \\
\hline Others (\%) & $\mathrm{A}$ & $\mathrm{B}$ & $\mathrm{C}$ & $\mathrm{D}$ \\
\hline Moisture & 39.92 & 41.12 & 40.6 & 57.25 \\
\hline $\mathrm{PH}$ & 6.95 & 6.98 & 6.97 & 7.0 \\
\hline & 13.8 & 13.0 & 12.8 & 28 \\
\hline
\end{tabular}

Evaluated soil samples in the study had $\mathrm{pH}$ and electrical conductivity ranging from 6.95 to 7.0 and 12.8 to $28 \%$ respectively. The highest level of organic carbon was observed in sample A $(0.96 \%)$, followed by $\mathrm{C}(0.68 \%)$ then $\mathrm{D}$ with $(0.20)$ and B with (0.08), organic matter was also recorded high in A (1.68\%) followed by D $(0.34 \%)$ then B with $0.14 \%$ and lastly $C$ with $(0.045 \%)$. For moisture results demonstrated 39.92-41.12\%; A having the highest and C with the lowest while uncontaminated soil had $57.25 \%$.

C. E. C was found to be between $12.8-13.8 \%$ for location while the control was having $28 \%$. The compositions of $\mathrm{N}, \mathrm{P}$ and $\mathrm{K}$ elements ranged from $0.053-098 \%(\mathrm{~N})$, and $4.58-8.20 \%(\mathrm{P})$ and $5.13-$ $7.18 \%(\mathrm{~K})$, with the uncontaminated soil having $1.035 \%(\mathrm{~N})$ and $7.00 \%(\mathrm{P})$ and $2.0 \%(\mathrm{~K})$. Organic matter $0.14-1.68 \%$, while uncontaminated soil sample $0.34 \%$.

The result for $\mathrm{Na}$ and $\mathrm{Mg}$ were $2.52-2.91 \%$ and $16.20 \%, 16.85 \%$ while Control was $0.2 \%(\mathrm{Na})$ and $15.90 \%(\mathrm{Mg})$.

Organic matter $0.1-0.6 \%$ while control was $0.34 \%$. This results is in line with other previous findings as in $[14,20,22,23]$. The results of particle soil analysis revealed high content of sandy soil (95.1 to 87.3).

Clay have the highest with $4.5 \%$, followed by $4.3 \%$ then 4.0 while control had $2.0 \%$ and finally.

Silt with B having $0.11 \%$ then $C$ had 0.8 followed by 0.6 and control had $2.5 \%$.

$\mathrm{pH}$ is an important soil property, having great effects on solute concentration and absorption in soil [2]. Soils with acidic pH levels tend to have an increased micronutrient solubility and mobility as well as increased heavy metal concentration. The levels of exchangeable cations $(\mathrm{Na}+, \mathrm{K}+$, $\mathrm{Ca} 2+, \mathrm{Mg} 2+$ ) is a reflection of soil condition with regards to the agricultural potential of soil at the study sites. Nitrogen is an important constituent of protein and nucleic acid and most microorganisms and plants take up inorganic nitrogen as nitrate (NO3-) or ammonium (NH4+) ions [2, 29].

Four genera of fungi were isolated from the oil contaminated soil samples and the control sample. The types of meld identified from the four samples include Penicillium sp. which was predominant. Table 2 shows the type of mycoflora isolated from the three samples of oil contaminated soil and the control.

Table 2 - Fungal Species Isolated from Oil Contaminated and uncontaminated Soil Samples

\begin{tabular}{|c|c|c|c|c|}
\hline \multirow{2}{*}{ Samples } & \multicolumn{4}{|c|}{ Fungi Isolated } \\
\cline { 2 - 5 } & Aspergillus sp. & Mucor sp. & Penicllium sp. & Sporobolomyces sp. \\
\hline A & - & - & + & - \\
\hline B & - & - & + & - \\
\hline C & + & + & - & + \\
\hline D & + & - & + & \\
\hline
\end{tabular}

Notes: Samples A - Buzaye, B - Sahara, C - Illela garage, Sample D - Oil uncontaminated soil (temporary site) 
Apergillus sp. was found in two locations C (Illela garage) and $\mathrm{D}$ (control) while it was not detected in the remaining two locations, Mucor sp. was found in location $\mathrm{C}$ only and not detected in the remaining locations including control, Penecillium $s p$. was found in all the locations except $\mathrm{C}$, and finally, Sporobolomyces sp. was detected in two locations namely; $\mathrm{B}$ and $\mathrm{D}$ while the two other locations it was not detected, this could be traced in similar research as in $[14,16,22]$.

\section{CONCLUSIONS}

Soil is basically the primary recipient of daily generated wastes at different places been it industries, markets and automobiles waste from mechanics, the quality of soil is always remains with its chemical and biological components. The occurrence of the four fungal species among the soil samples in the selected automobile garage, Sokoto Metropolis, indicates the capacity of the fungal species to adapt in oil contaminated soils. This suggests that they are potential hydrocarbon degraders and therefore can be used for the remediation of petroleum sites which happen to be polluted. The effect of these wastes on the soil ecosystem is not surprising considering the tendency for pollutants to alter soil quality. Therefore, informing the public of the dangers inherent in improper management of soil environment should be considered as an important aspect of scientific research and awareness.

It is therefore recommended that more investigation should be carried out into the biochemical pathways employed by these isolates in the breakdown of petroleum by-products for their possible application to ensure extensive clear of petroleum by-products contaminated sites.

\section{REFERENCES}

1. Abdus-Salam, N. (2009). Assessment of Heavy Metals Pollution in Dumpsites in Ilorin Metropolis. Ethiopian Journal of Environmental Studies and Management, 2(2). doi: 10.4314/ejesm.v2i2.45926

2. Akpoveta, O., Osakwe, S., Okoh, B., \& Otuya, B. (2011). Physicochemical Characteristics and Levels of Some Heavy Metals in Soils around Metal Scrap Dumps in Some Parts of Delta State, Nigeria. Journal of Applied Sciences and Environmental Management, 14(4). doi: 10.4314/jasem.v14i4.63258

3. Al-Wasify, R. S., \& Hamed, S. R. (2014). Bacterial Biodegradation of Crude Oil Using Local Isolates. International Journal of Bacteriology, 2014, 1-8. doi: 10.1155/2014/863272

4. Chukwura, E. I., Ojiegbu, N. M., \& Nwankwegu, A. S. (2016). Hydrocarbon degradation potentials of fungi associated with oil-contaminated soil from selected mechanic workshops in Awka, Anambra State, Nigeria. Frontiers in Environmental Microbiology, 2, 38-44.

5. Coleman, D. C., Callaham, M. A., \& Crossley Jr, D. (2017). Fundamentals of soil ecology. Amsterdam: Academic press.

6. Eldor, P. A. (2015). Soil microbiology, ecology and biochemistry. Amsterdam: Academic press.

7. EL-Morsy, E.-S. M. (2005). Evaluation of microfunghi for the bioremediation of diesel oil in Egypt. Land Contamination \& Reclamation, 13(2), 147-159. doi: 10.2462/09670513.663

8. Eze, V., Omeh, Y., \& Ugweje, C. (2013). Microbiological and Physicochemical Assessment of Soil Contaminated with Lairage Effluent in Umuahia, Abia State, Nigeria. Journal of Pharmacy and Biological Sciences, 8(2), 50-56.

9. Fuentes, S., Méndez, V., Aguila, P., \& Seeger, M. (2014). Bioremediation of petroleum hydrocarbons: catabolic genes, microbial communities, and applications. Applied Microbiology and Biotechnology, 98(11), 4781-4794. doi: 10.1007/s00253-014-5684-9

10. Gbadebo, A., Taiwo, A., \& Eghele, U. (2010). Environmental impacts of drilling mud and cutting wastes from the Igbokoda onshore oil wells, Southwestern Nigeria. Indian Journal of Science and Technology, 3(5), 504-510. 
11. Hibbett, D. S., Binder, M., Bischoff, J. F., Blackwell, M., Cannon, P. F., Eriksson, O. E., ... Lücking, R. (2007). A higher-level phylogenetic classification of the Fungi. Mycological Research, 111(5), 509-547. doi: 10.1016/j.mycres.2007.03.004

12. Hillel, D. (2013). Fundamentals of soil physics. Amsterdam: Academic press.

13. Hillel, D. (2013). Introduction to soil physics. Amsterdam: Academic press.

14. Imarhiagbe, E., Osarenotor, O., Obayagbona, O., Eghomwanre, A., \& Nzeadibe, B. (2017). Evaluation of physicochemical, microbiological and polycyclic aromatic hydrocarbon content of top soils from Oka Market Waste Collection Site, Benin City, Nigeria. Journal of Applied Sciences and Environmental Management, 21(1), 112-117.

15. Isbell, F., Reich, P. B., Tilman, D., Hobbie, S. E., Polasky, S., \& Binder, S. (2013). Nutrient enrichment, biodiversity loss, and consequent declines in ecosystem productivity. Proceedings of the National Academy of Sciences, 110(29), 11911-11916. doi: 10.1073/pnas.1310880110

16. Lawal, M. O., Samuel, O. B., Mogekwu, T. O., \& Bolaji, D. A. (2013). Toxicity of Two Household Liquid Soaps on Poecilia reticulata Peters, 1859. Brazilian Journal of Aquatic Science and Technology, 17(1), 35. doi: 10.14210/bjast.v17n1.p35-41

17. McNamara, N. P., Black, H. I. J., Beresford, N. A., \& Parekh, N. R. (2003). Effects of acute gamma irradiation on chemical, physical and biological properties of soils. Applied Soil Ecology, 24(2), 117-132. doi: 10.1016/s0929-1393(03)00073-8

18. Murphy, H. F. (1929). Some effects of crude petroleum on nitrate production, seed germination, and growth. Soil Science, 27(2), 117-120. doi: 10.1097/00010694-192902000-00004

19. Ngozi, V., Wirnkor, V., \& Ebere, E. (2017). Pollution assessment models of surface soils in Port Harcourt city, Rivers State, Nigeria. World News of Natural Sciences, 12, 1-20.

20. Obayagbona, N. O., \& Enabulele, O. I. (2013). Biodegradation potentials of automobile workshop soil mycoflora on flow station petroleum sludge with an extra carbon source. The Journal of Microbiology, Biotechnology and Food Sciences, 3(1), 19-25.

21. Obi, M. (2000). Soil physics: A compendium of lectures. Nsukka: Atlanto Publishers.

22. Odiba, J. O., Matthew, O. A., \& Chrysanthus, A. (2017). Evaluation of the physicochemical and heavy metal content of ground water sources in Bantaji and Rafin-Kada settlements of Wukari Local Government Area, Taraba State, Nigeria. Journal of Environmental Chemistry and Ecotoxicology, 9(4), 43-53. doi: 10.5897/jece2017.0416

23. Ologbosere, O. A., Aluyi, H. S. A., Ogofure, A. G., Beshiru, A., \& Omeje, F. I. (2016). Physico-chemical and microbiological profile of bacterial and fungal isolates of Ikpoba River in Benin City: Public health implications. African Journal of Environmental Science and Technology, 10(3), 67-76. doi: 10.5897/ajest2015.1981

24. Parveen, S., Iqbal, M. Z., Shafiq, M., \& Athar, M. (2014). Effect of automobile polluted soil on early seedling growth performance of Neem (Azadirachta indica A. Juss.). Advances in Environmental Research, 3(1), 1-9. doi: 10.12989/aer.2014.3.1.001

25. Rathi, S. (2006). Alternative approaches for better municipal solid waste management in Mumbai, India. Waste Management, 26(10), 1192-1200. doi: 10.1016/j.wasman.2005.09.006

26. Ren, P., Jankun, T. M., \& Leaderer, B. P. (1999). Comparisons of seasonal fungal prevalence in indoor and outdoor air and in house dusts of dwellings in one Northeast American county. Journal of Exposure Science \& Environmental Epidemiology, 9(6), 560-568. doi: 10.1038/sj.jea.7500061

27. Sharholy, M., Ahmad, K., Mahmood, G., \& Trivedi, R. C. (2008). Municipal solid waste management in Indian cities - A review. Waste Management, 28(2), 459-467. doi:

10.1016/j.wasman.2007.02.008 
28. Udo, E. J., \& Fayemi, A. A. A. (1975). The Effect of Oil Pollution of Soil on Germination, Growth and Nutrient Uptake of Corn1. Journal of Environment Quality, 4(4), 537. doi: 10.2134/jeq1975.00472425000400040023x

29. Watkar, A., \& Barbate, M. (2012). Annual Changes in Physico-Chemical Parameters of the Effluents of Pulpand Paper Mill in Saoner Region. Bionano Frontier, 16(1), 41-43.

30. Zhai, Y., Cui, L., Zhou, X., Gao, Y., Fei, T., \& Gao, W. (2013). Estimation of nitrogen, phosphorus, and potassium contents in the leaves of different plants using laboratory-based visible and nearinfrared reflectance spectroscopy: comparison of partial least-square regression and support vector machine regression methods. International Journal of Remote Sensing, 34(7), 2502-2518. doi: $10.1080 / 01431161.2012 .746484$ 